Article

\title{
Weed Infestation and Health of the Soybean Crop Depending on Cropping System and Tillage System
}

\author{
Dorota Gawęda ${ }^{1}\left(\mathbb{0}\right.$, Małgorzata Haliniarz ${ }^{1, *(0)}$, Urszula Bronowicka-Mielniczuk ${ }^{2}{ }^{(1)}$ and \\ Justyna Lukasz ${ }^{1}$ \\ 1 Department of Herbology and Plant Cultivation Techniques, University of Life Sciences in Lublin, \\ Akademicka 13, 20-950 Lublin, Poland; dorota.gaweda@up.lublin.pl (D.G.); \\ justynalukasz1992@gmail.com (J.Ł.) \\ 2 Department of Applied Mathematics and Computer Science, University of Life Sciences in Lublin, \\ Głęboka 28, 20-612 Lublin, Poland; urszula.bronowicka@up.lublin.pl \\ * Correspondence: malgorzata.haliniarz@up.lublin.pl; Tel.: +48-81-4456654
}

Received: 16 April 2020; Accepted: 5 June 2020; Published: 7 June 2020

Abstract: This study evaluated weed infestation and health of the soybean crop grown in crop rotation (CR) and monoculture (CM) under conventional tillage (CT) and no-tillage (NT) conditions. The research proved that growing soybean in monoculture and under no-tillage conditions increases weed infestation and infection of soybean with fungal diseases. In these treatments, increased numbers of most of the dominant species were also found. A significantly higher percentage of monocotyledonous species and a much lower percentage of dicotyledonous ones in total weed dry weight were shown in the CR treatment relative to CM and in the NT system compared to CT. The biodiversity of the weed community was similar in monoculture and crop rotation, and slightly greater in the NT system in comparison with CT conditions. In both tillage systems, Amaranthus retroflexus was the weed species that most infested the soybean crop. In soybean grown after itself, Amaranthus retroflexus was the weed that occurred in the greatest numbers, while, in crop rotation, this was Echinochloa crus-galli. In all years of the study, soybean was infected with Septoria glycines to the highest degree, which was followed by Cercospora sojina, whereas infection with Ascochyta sp. was the lowest. Weather conditions in individual years of the study were proven to affect weed infestation and infection of soybean with fungal diseases. The study results prove that cropping systems and tillage systems significantly affect weed infestation and health of the soybean crop.

Keywords: Glycine max (L.) Merr.; cropping system; tillage system; weed infestation; biological diversity; fungal diseases

\section{Introduction}

Soybean is one of the world's leading crops and, at the same time, the most important Fabaceae species. It is characterized by a very valuable chemical seed composition because soybeans contain $18-22 \%$ of oil with a high content of unsaturated fatty acids and $33-45 \%$ protein with an excellent amino acid composition [1,2]. Due to this, the soybean finds a very wide application in human and animal nutrition, and it is a raw material for many branches of industry. Since soybeans can be grown with minimal use of chemical protection (primarily herbicides) and with reduced nitrogen fertilization, under Polish conditions, soybean cultivation is environmentally-friendly and largely compatible with integrated crop protection [2].

In Poland, the general principles of integrated crop protection are governed by the provisions of the Act of 8 March 2013 on crop protection products (Dz. U. (Journal of Laws) item 455) and the Regulation of the Minister of Agriculture and Rural Development of 18 April 2013 regarding requirements for 
integrated crop protection (Dz. U. (Journal of Laws) item 505) [3]. In accordance with the currently applicable principles of integrated crop protection, a great role is ascribed to natural fertility of soil and its biological activity. Therefore, the number of ploughings and their depth should be reduced and other implements that deeply loosen the soil without turning it over should be used instead of the plough [2]. The destructive impact of conventional plough tillage on the structure of the topsoil layer and reduced soil biological diversity, among others, make an argument for its abandonment [4,5]. When selecting a tillage system, the specific conditions of a particular farm should be taken into consideration in order to ensure optimal plant growth and developmental conditions [6,7]. Cultural practices affect the amount of crop residue remaining on the soil surface, which, in consequence, determines the growth of pests and weeds as well as the development of diseases [8,9]. Exact mixing of crop residue on which crop pathogens could have survived with soil is considered to be one of the tasks of conventional tillage [10]. On the other hand, an improvement in soil quality, the level of microbial activity, nutrient cycling, and microbial diversity that can be achieved by using no-tillage systems can significantly determine natural resistance of plants to diseases [11].

It is particularly justified to use no-tillage in soybean under rainfall deficit conditions during a growing season. The yield potential of this legume crop is substantially limited by climatic conditions, predominant temperature, and the amount and distribution of rainfall $[12,13]$. Therefore, in areas with low rainfall levels, it is important to use cultural practices that will ensure retention of the greatest possible amount of rainwater. Agronomic practices that involve replacing the plough with implements and do not turn the soil over offer such a possibility. Thus, no-tillage performs best in a dry climate or in a climate with an uneven distribution of rainfall where crop yields are frequently equal to or higher than in the case of conventional tillage [14].

A correctly designed crop rotation is also the basis for the integrated crop protection system. Monoculture impoverishes both organic matter and soil microbial life $[15,16]$, which leads to increased weed infestation, and deteriorates the phytosanitary condition of a crop [17-19]. Due to the fact that, under Polish conditions, soybeans are not severely attacked by dangerous diseases, an attempt was made to investigate its response when it is grown a in short-term monoculture.

The aim of the present study was to evaluate the effect of the cropping system and tillage system on weed infestation and health of the soybean crop.

\section{Materials and Methods}

\subsection{Location of the Experiment and Soil and Climatic Conditions}

This study was conducted at the Uhrusk Experimental Farm $\left(51^{\circ} 18^{\prime} 11^{\prime \prime} \mathrm{N}, 23^{\circ} 36^{\prime} 50^{\prime \prime}\right.$ E) over the period of 2014 to 2017. A field experiment was set up on Rendzic Phaeozem [20] with the grain-size distribution of sandy loam. The soil on which the experiment was carried out was characterized by alkaline $\mathrm{pH}$ (in $1 \mathrm{M} \mathrm{KCl}=7.7)$, very high phosphorus availability $\left(229.8 \mathrm{mg} \mathrm{P} \mathrm{kg}^{-1}\right.$ soil), high potassium availability (150.2 $\mathrm{mg} \mathrm{K} \mathrm{kg}^{-1}$ soil), and very low magnesium availability (16 $\mathrm{mg} \mathrm{Mg} \mathrm{kg}^{-1}$ soil). The humus content was $1.5 \%$, whereas the percentage of fine particles $(<0.02 \mathrm{~mm})$ in the $0-30 \mathrm{~cm}$ layer amounted to $20.7 \%$.

Throughout the duration of the experiment, all growing seasons of soybeans were characterized by a higher mean air temperature and rainfall total than the long-term mean (Figures 1 and 2). 


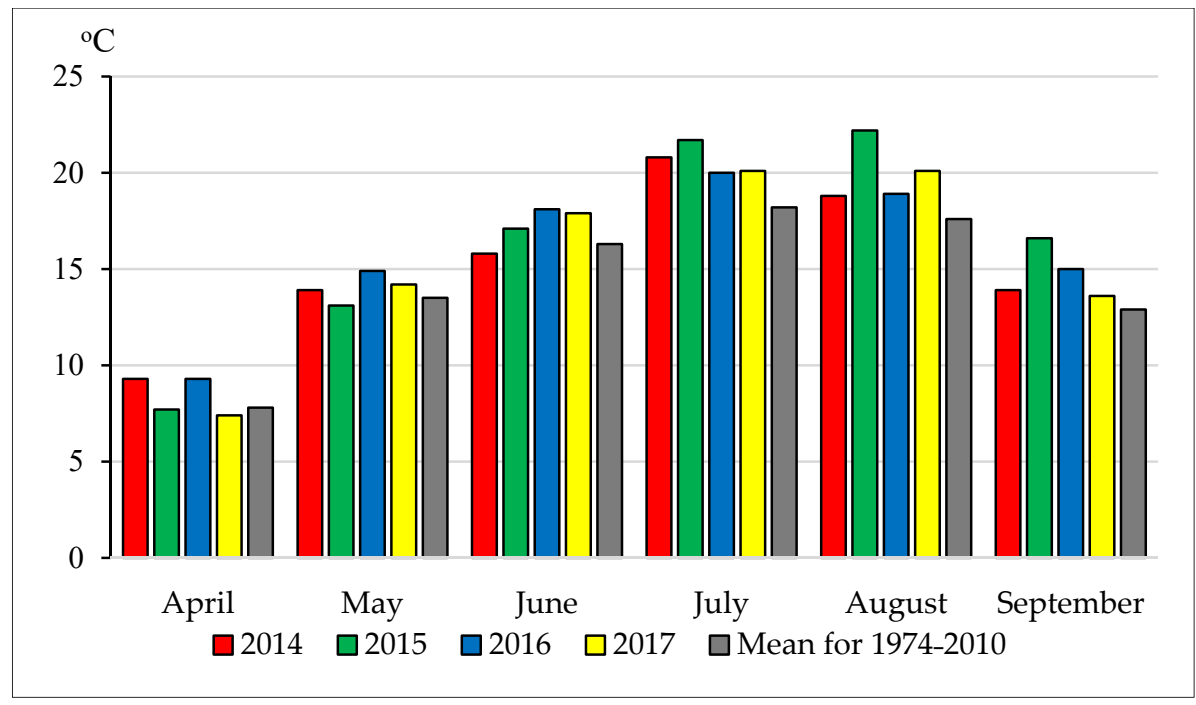

Figure 1. Mean monthly air temperature $\left({ }^{\circ} \mathrm{C}\right)$ at the Bezek Meteorological Station from 2014 to 2017.

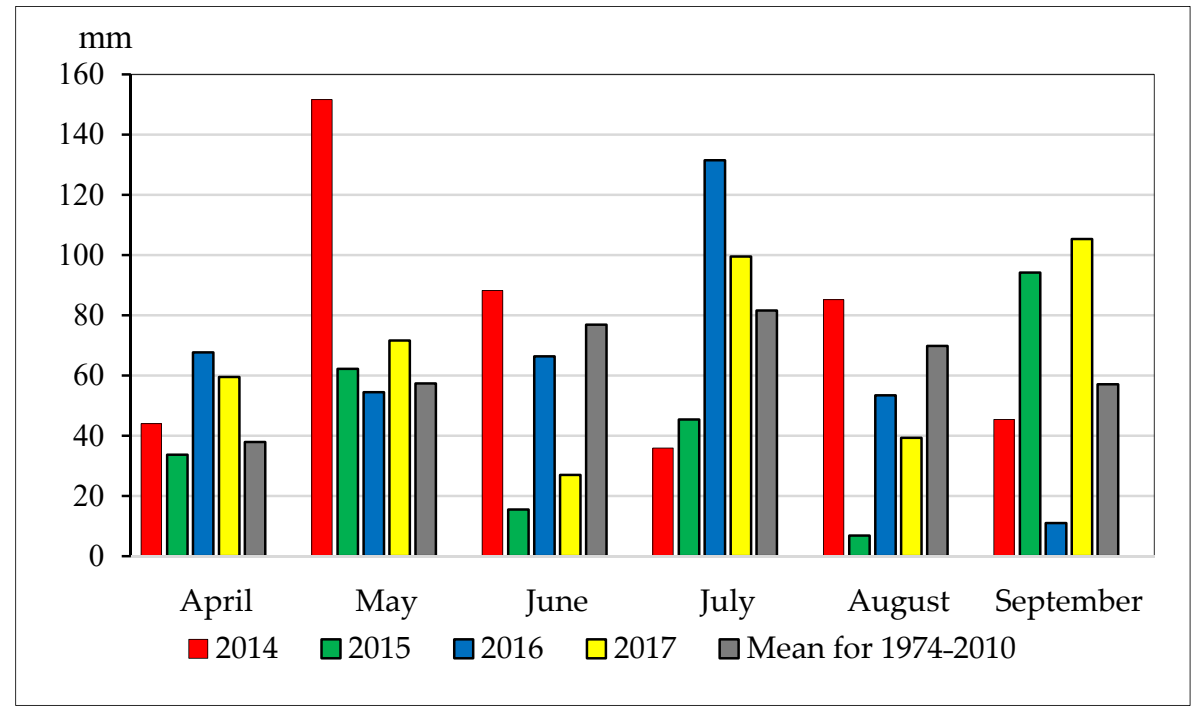

Figure 2. Total rainfall and rainfall distribution (mm) at the Bezek Meteorological Station from 2014 to 2017.

\subsection{Experimental Design and Agronomic Practices}

The soybean cultivar 'Merlin' was grown in an experimental area of $768 \mathrm{~m}^{2}$ (area of all crops in crop rotation) and $192 \mathrm{~m}^{2}$ (area of soybean in monoculture). The total area of the soybean in each year of the experiment was $384 \mathrm{~m}^{2}$ (soybeans in crop rotation had a total area of $192 \mathrm{~m}^{2}$ and soybeans in a monoculture had a total area of $192 \mathrm{~m}^{2}$ ), while the single plot area was $32 \mathrm{~m}^{2}$. A field experiment was set up as a split-block design in triplicate. Two experimental factors were included in this study.

I. CS-cropping system: $\mathrm{CR}$ - soybean grown in crop rotation after winter wheat (crop rotation: soybean—winter wheat—winter oilseed rape—winter wheat), $\mathrm{CM}$-soybean monoculture cropping.

II. TS—tillage system: CT—conventional tillage, NT—no-tillage.

The experiment diagram shows the distribution of the cropping system and tillage systems and the place of soybeans in crop rotation during individual years of the experiment (Table 1). In each year of the research, soybean was sown in a different crop rotation field after winter wheat. Levels of one factor (cropping system involving crop rotation and monoculture) are arranged in rows, and levels 
of the second factor (tillage system involving conventional tillage and no-tillage) are arranged in columns. The levels of both factors arranged perpendicularly are crossed to form a combination of these factors. Random levels of one factor determined sub-blocks for levels of the other factor and vice versa. Therefore, the accuracy of assessing the effects of both factors is the same. In all years of research, conventional tillage (CT) and no-tillage (NT) was used for all plants sown in crop rotation $(\mathrm{CR})$ and the soybean monoculture (CM).

Table 1. Experiment scheme. *Soybean location in the experiment. $\mathrm{CR}$-crop rotation, $\mathrm{CM}-$ monoculture, CT-plough tillage, NT-no-tillage.

\begin{tabular}{|c|c|c|c|c|c|c|c|}
\hline & CT & NT & CT & NT & CT & NT & \\
\hline $\mathrm{CM}$ & CM CT & CM NT & CM CT & CM NT & CM CT & CM NT & $\begin{array}{l}\text { *soybean } \\
2014-2017\end{array}$ \\
\hline \multirow{5}{*}{$\mathrm{CR}$} & CR CT & CR NT & CR CT & CR NT & CR CT & CR NT & *soybean 2015 \\
\hline & CR CT & CR NT & CR CT & CR NT & CR CT & CR NT & *soybean 2016 \\
\hline & CR CT & CR NT & CR CT & CR NT & CR CT & CR NT & *soybean 2017 \\
\hline & CR CT & CR NT & CR CT & CR NT & CR CT & CR NT & *soybean 2014 \\
\hline & \multicolumn{2}{|c|}{ replicates I } & repl & ites II & \multicolumn{2}{|c|}{ replicates III } & \\
\hline
\end{tabular}

Under the conventional tillage system, the following tillage operations were carried out: skimming + harrowing, harrowing, autumn ploughing, spring: harrowing, NPK fertilizers application, cultivating with harrowing, seeding, and harrowing. Under the no-tillage system, the following tillage operations were done: stubble cultivator: grubber + cage roller instead of skimming and cultivating instead of autumn ploughing, and spring: the same tillage operations as under the conventional tillage system.

Mineral NPK fertilization was applied before sowing soybean and fertilizer rates were determined by taking into account the crop's nutritional requirements and soil nutrient availability. Fertilization was applied at the following rates: $\mathrm{N} \_30 \mathrm{~kg} \mathrm{ha}^{-1}$ ( $34.5 \%$ ammonium nitrate), $\mathrm{P} \_40 \mathrm{~kg} \mathrm{ha}^{-1}$ ( $40 \%$ superphosphate), and $\mathrm{K}-80 \mathrm{~kg} \mathrm{ha}^{-1}$ (60\% potassium salt).

In the years 2014 and 2016, the sowing time was in the last 10 days of April, whereas, in 2015 and 2017, the sowing time was in the first 10 days of May. Each time before sowing, seeds were dressed with Bradyrhizobium japonicum bacteria and the seed dressing Vitavax 200 FS (carboxin, thiuram) at a rate of $80 \mathrm{~g}$ and $80 \mathrm{~g}$ (active ingredients) per $100 \mathrm{~kg}$ of seeds. Seeds were sown at a depth of $3 \mathrm{~cm}$, a row spacing of $20 \mathrm{~cm}$, and with a planned density of 100 plants per $1 \mathrm{~m}^{2}$.

Weed management in the soybean crop involved mechanical and chemical weed control. Immediately after seeding, a mixture of the following herbicides was applied: Afalon Dyspersyjny 450 SC (linuron) + Dual Gold $960 \mathrm{EC}$ (metolachlor-S) at a rate of $450 \mathrm{~g}+1728 \mathrm{~g} \mathrm{ha}^{-1}$ (active ingredients). Mechanical weed control included harrowing 3-4 days after seeding and double harrowing after emergence of soybeans (at the first trifoliate leaf stage- $-\mathrm{BBCH} 12$, and at the third trifoliate leaf stage-BBCH 13).

Soybeans were harvested at full maturity of soybeans (BBCH 89) in the second 10 days of September in 2014 and 2016, while, in 2015 and 2017, soybeans were harvested at full maturity in the third 10 days of September.

\subsection{Scope of Study and Statistical Analysis}

The evaluation of the species' composition of the weed community as well as of weed density and dry weight, which was performed by the dry-weight-rank method at the pod and seed ripening stage (BBCH 81/82). The sampling area was delineated by a quadrat frame with the dimensions of $1 \mathrm{~m} \times 0.5 \mathrm{~m}$ in two randomly selected points of each plot. Weed species nomenclature followed Mirek et al. [21]. 
The Shannon-Wiener diversity index $\left(H^{\prime}\right)$ and the Simpson dominance index $(S I)$ were calculated according to the following formula [22,23].

$$
\begin{gathered}
H^{\prime}=-\sum \mathrm{Pi} \ln \mathrm{Pi} \\
S I=\Sigma \mathrm{Pi} 2
\end{gathered}
$$

where:

$\mathrm{Pi}$-probability of species occurrence in a sample,

$\mathrm{Pi}=\mathrm{n} / \mathrm{N}$,

$\mathrm{n}$-number of individuals in species,

$\mathrm{N}$-total number of individuals in the sampling area,

ln-natural logarithm.

The higher the value of the Shannon-Wiener index, the greater the diversity of a community. The range of Simpson index values is from 0 to 1 with values close to 1 indicating a clear dominance of one or several species.

The evaluation of soybean health was carried out at the first pod set stage (BBCH 70) on 50 plants from each plot. The determination was made using a five-point scale (0-4) expressing increasing plant infection, where 0 denotes leaves without disease symptoms, 1 denotes up to $10 \%$ of leaf surface infected, 2 represents up to $50 \%, 3$ represents up to $75 \%$, and 4 represents 100\% of leaf surface infected. Having established the degree of plant infection, the number of plants within a specific degree of infection was determined for all replicates. Next, the disease index was calculated according to McKinney's formula [24].

$$
W c h=\left(\sum \mathrm{a}\right) /\left(\sum \mathrm{b}\right) \times 100
$$

where:

Wch-disease index;

$\Sigma a-$ sum of the numeric indices in the scale multiplied by the number of plants corresponding to a given index;

$\Sigma \mathrm{b}$-total number of examined plants multiplied by the highest index in the scale.

The study results collected over the period 2014-2017 were analyzed using two-way analysis of variance with repeated measurements over the four growing periods. The significance of differences was estimated by Tukey's test at a significance level of $\alpha=0.05$. ANALWAR-5.3.FR statistical software was used for calculations. The distribution conformity with normal distributions was verified with the Shapiro-Wilk test, while homogeneity of the variance was tested with the Bartlett test. When necessary to homogenize the variance, the data were subjected to angular transformation before the variance analysis [25]. Before performing the statistical calculations, the percentage values were transformed using the following equation.

$$
y=\arcsin \sqrt{x}
$$

\section{Results}

\subsection{Weed Infestation of Soybean Crops}

Cropping systems and tillage systems caused significant differences in weed infestation of the soybean crop (Figures 3 and 4). On average over the study period, in the soybean monoculture, the number and dry weight of weeds was, respectively, higher by $69.4 \%$ and $28.6 \%$ than in crop rotation. The significant interactions between the cropping system and the tillage system were not found (Figures 5 and 6). The weed of dry weight did not differ between both tillage systems only in the first year of the experiment. The highest weed of dry weight was found in 2014 in the soybean monoculture both under plough tillage (CT) and no-tillage (NT) conditions. Weed infestation of the soybean crop expressed as dry weight of weeds was highest in the first year of the experiment (2014), which was characterized by a higher amount of precipitation than the other years of the experiment 
and the long-term mean, especially in May and June. The lowest number and dry weight of weeds were found in 2015 and 2016 (Figures 3 and 4).

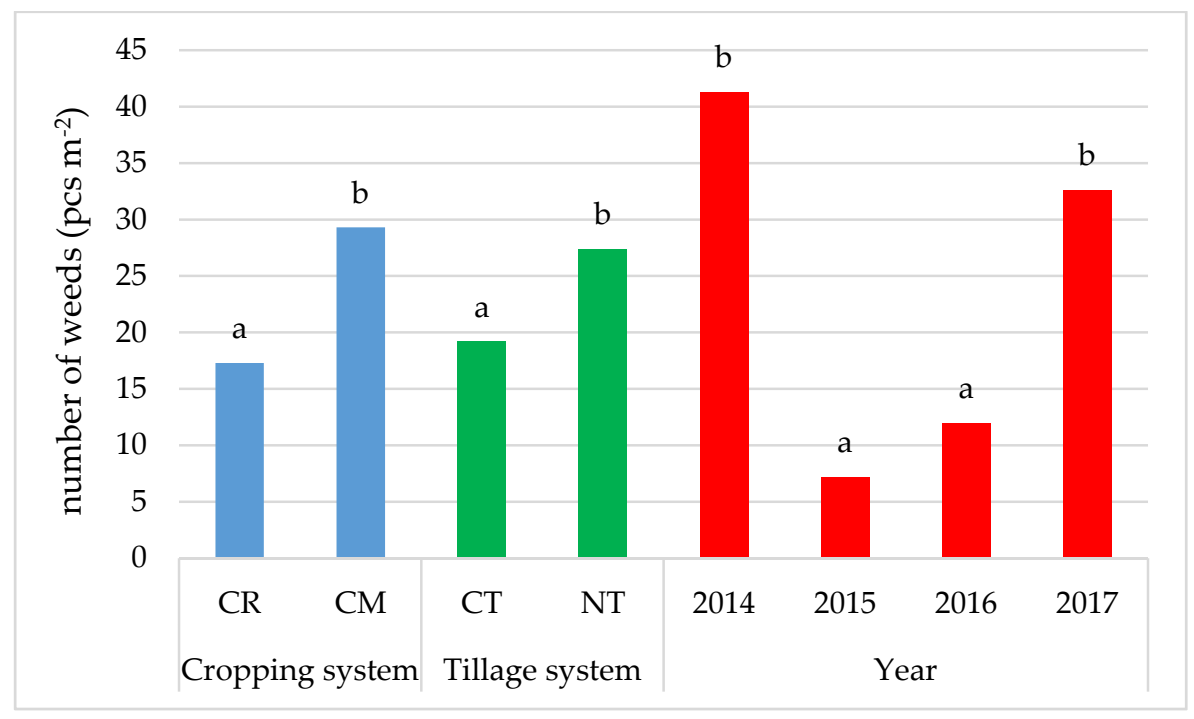

Figure 3. Mean number of weeds in soybean crop depending on cropping system, tillage system, and years of research. $\mathrm{CR}$ - crop rotation, $\mathrm{CM}-$ monoculture, $\mathrm{CT}-$ plough tillage, and NT—no-tillage. Different letters denote significant differences $(p \leq 0.05)$ among different cropping systems $(\mathrm{CR}$ and $\mathrm{CM})$, tillage systems (CT and NT), and years of research. The same letter means it is not significantly different.

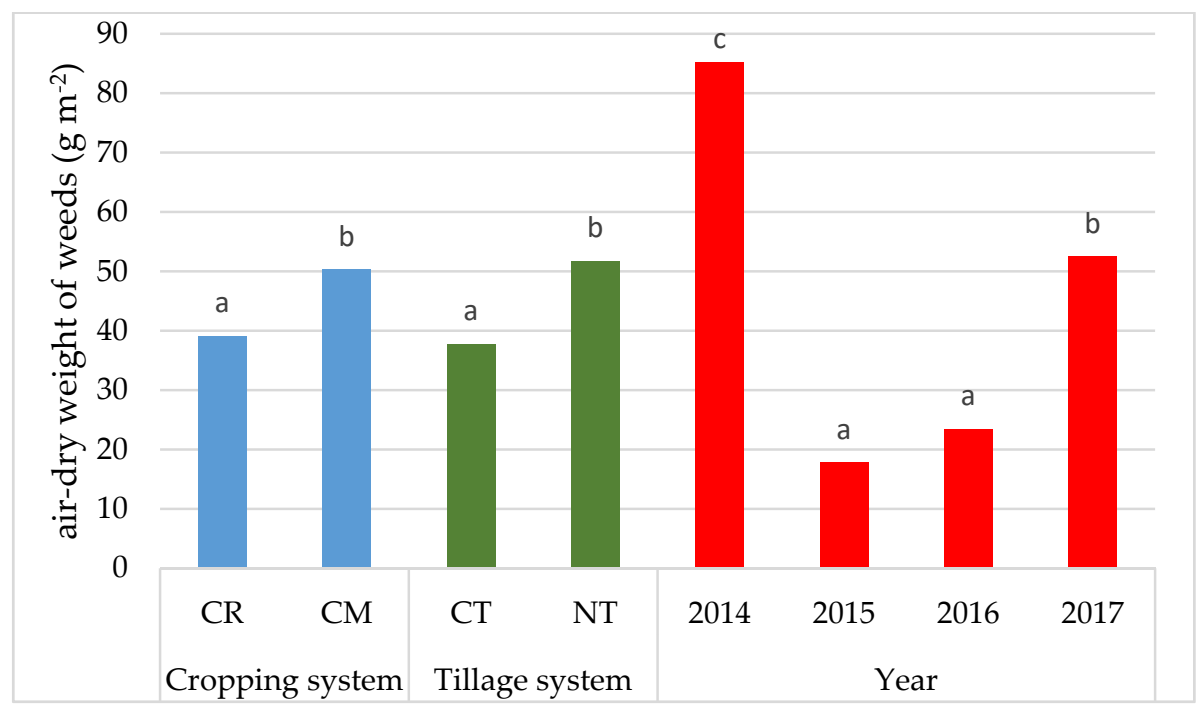

Figure 4. Air-dry weight of weeds in soybean crop depending on cropping system, tillage system, and years of research. $\mathrm{CR}$-crop rotation, $\mathrm{CM}-$ monoculture, CT-plough tillage, NT-no-tillage. Different letters denote significant differences $(p \leq 0.05)$ among different cropping systems (CR and $C M)$, tillage systems (CT and NT), and years of research. The same letter means it is not significantly different.

The statistical analysis revealed that the studied factors significantly modified the percentage of monocotyledonous and dicotyledonous species in total weed dry weight (Figure 7). In crop rotation $(\mathrm{CR})$, the percentage of monocotyledonous species was significantly higher, whereas the percentage of dicotyledonous ones was much lower than in the soybean monoculture (CM). The NT system significantly increased the percentage of monocotyledonous species and decreased the percentage of dicotyledonous ones in total weed dry weight in comparison with the CT system. As far as the interactions between the experimental factors are concerned, it was proven that the percentage of 
monocotyledonous species in total weed dry weight was lower in the monoculture under conventional tillage conditions, while the percentage of dicotyledonous ones was higher relative to the other experimental treatments (Figure 8).

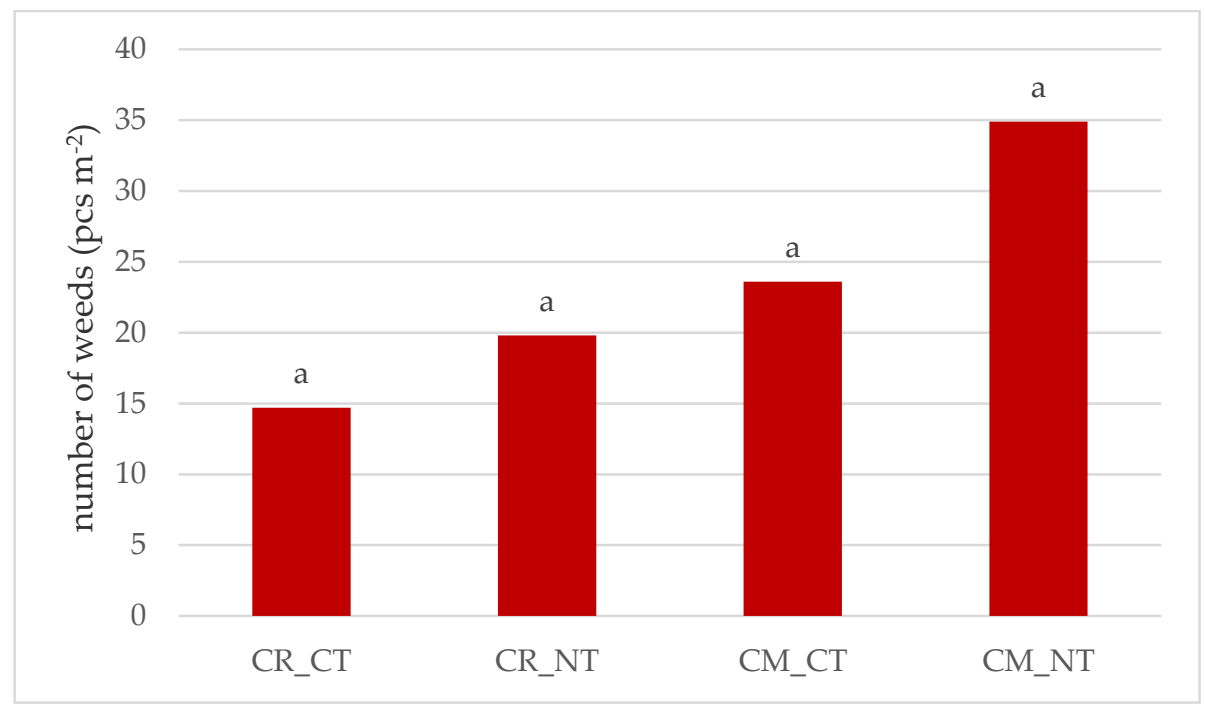

Figure 5. Interactive dependencies of the cropping system and tillage system in shaping the number of weeds in soybean crop (mean for 2014-2017). CR_CT—crop rotation and plough tillage, CR_NT—crop rotation and no-tillage, CM_CT-monoculture and plough tillage, CM_NT-monoculture and no-tillage. The same letter means it does not have a significantly different $(p \leq 0.05)$ interaction among crop rotation $(\mathrm{CR})$, monoculture (CM), plough tillage (CT), and no-tillage (NT).

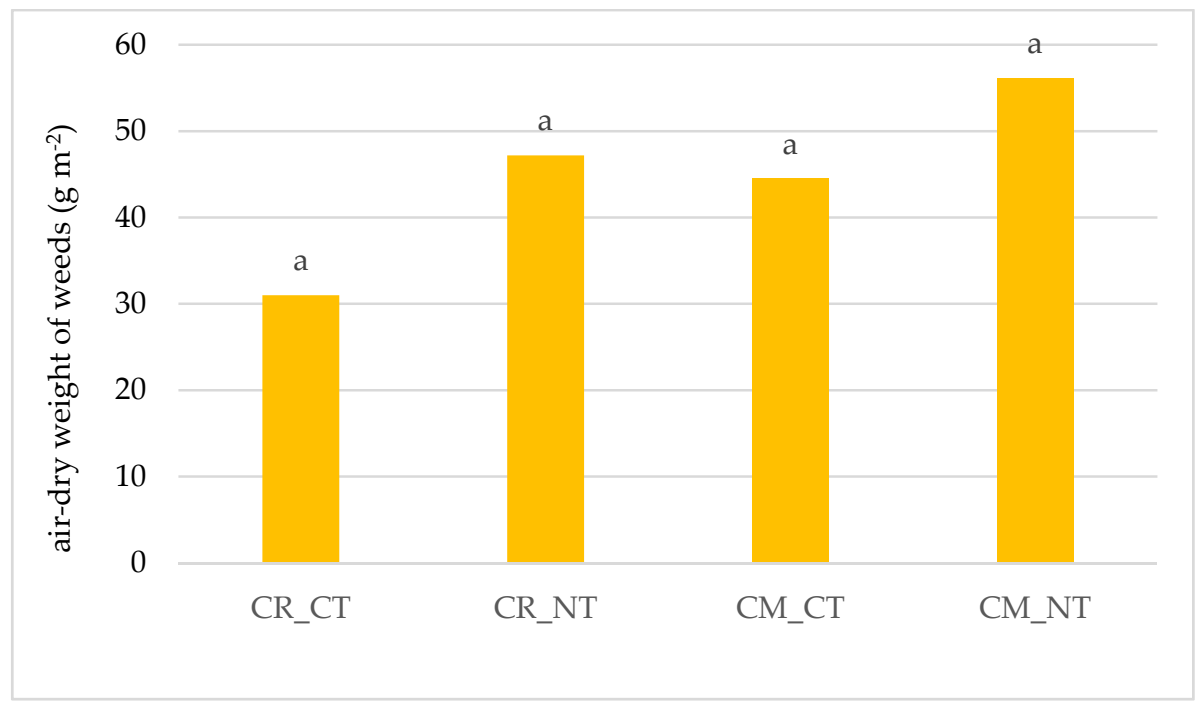

Figure 6. Interactive dependencies of the cropping system and tillage system in shaping air-dry weight of weeds in soybean crop (mean for 2014-2017). CR_CT—crop rotation and plough tillage, CR_NT—crop rotation and no-tillage, CM_CT-monoculture and plough tillage, CM_NT—monoculture and no-tillage. The same letter means it is not significantly different $(p \leq 0.05)$ in terms of the interaction among crop rotation $(\mathrm{CR})$, monoculture $(\mathrm{CM})$, plough tillage $(\mathrm{CT})$, and no-tillage (NT).

The agrophytocenosis of the soybean crop grown after winter wheat (CR) included 22 weed species out of which 18 belonged to annual weeds ( $81.8 \%$ ) (Table 2). Four perennial weed species and 17 annual ones, which accounted for $81.0 \%$ of the total number of species, were observed in a soybean monoculture (CM). In crop rotation, Echinochloa crus-galli was the most numerous taxon, followed by Amaranthus retroflexus, whereas, in a soybean monoculture, Amaranthus retroflexus was predominant. 
The number of Amaranthus retroflexus, Chenopodium album, Avena fatua, and Solanum nigrum was significantly higher in monoculture (CM) than in CR. Soybean cultivation in crop rotation (CR) also significantly reduced the numbers of the perennial species Elymus repens. In CR, Anchusa arvensis, Veronica persica, Viola arvensis, and Convolvulus arvensis were found to be present, but they did not inhabit soybeans grown after itself (CM). Euphorbia helioscopia, Thlaspi arvense, and Plantago major infested only a soybean monoculture.

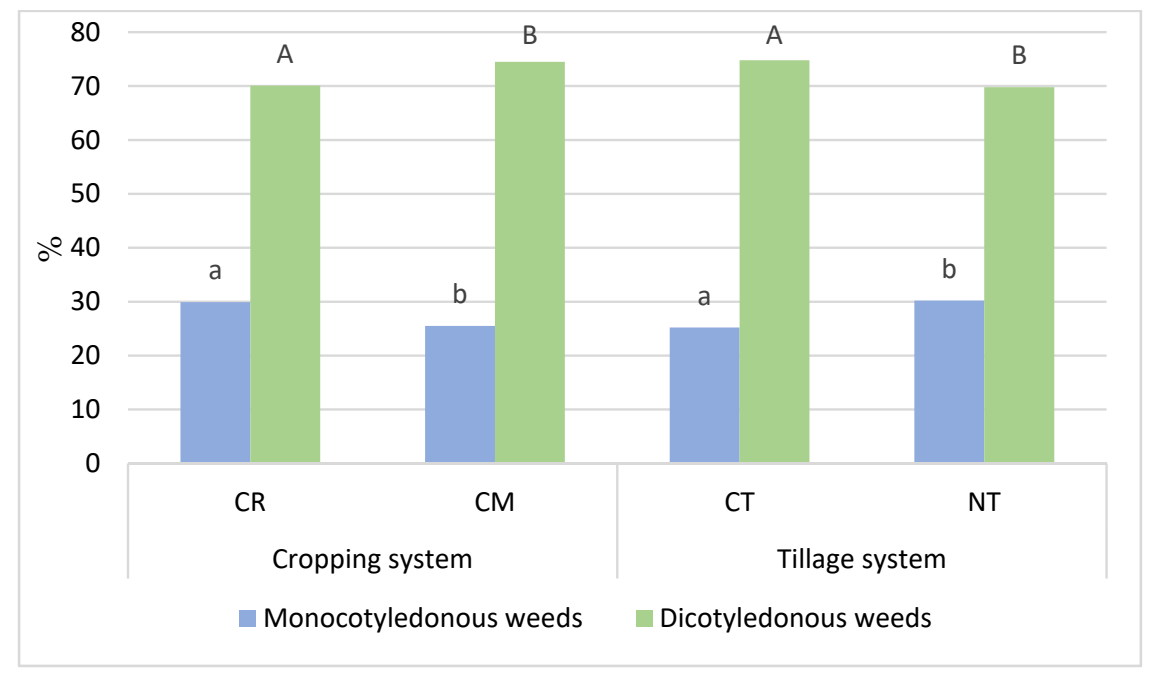

Figure 7. Percentage content of weight of monocotyledonous and dicotyledonous weeds in total weed dry weight depending on the cropping system and tillage system (mean for 2014-2017). CR—crop rotation, $\mathrm{CM}-$ monoculture, $\mathrm{CT}-$ plough tillage, NT-no-tillage. Different lowercase letters denote significant differences $(p \leq 0.05)$ of monocotyledonous weeds among different cropping systems (CR and $\mathrm{CM})$ and tillage systems (CT and NT). Different capital letters denote significant differences $(p \leq 0.05)$ of dicotyledonous weeds among different cropping systems (CR and CM) and tillage systems (CT and NT).

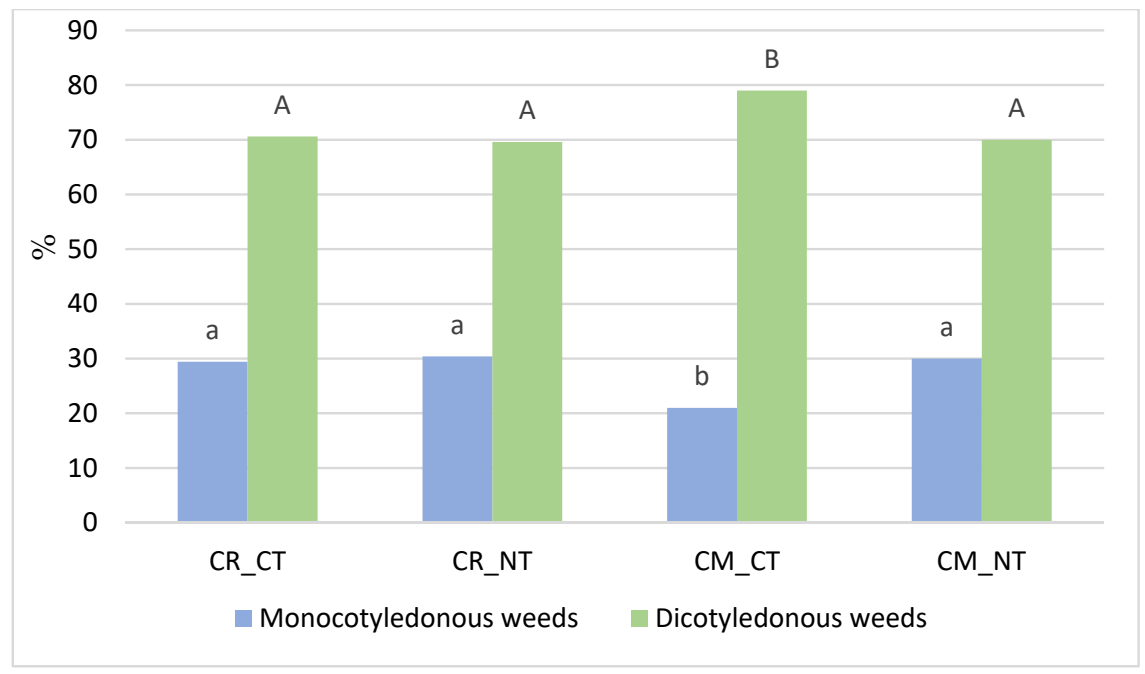

Figure 8. Percentage content of monocotyledonous and dicotyledonous weeds weight in total weed dry weight depending on the interaction of the cropping system and tillage system (mean for 2014-2017). CR_CT—crop rotation and plough tillage, CR_NT—crop rotation and no-tillage, CM_CT—monoculture and plough tillage, and CM_NT-monoculture and no-tillage. Different lowercase letters denote significant differences $(p \leq 0.05)$ of monocotyledonous weeds for interaction among crop rotation $(\mathrm{CR})$, monoculture (CM), plough tillage (CT), and no-tillage (NT). Different capital letters denote significant differences $(p \leq 0.05)$ of dicotyledonous weeds for interaction among crop rotation (CR), monoculture $(\mathrm{CM})$, plough tillage (CT), and no-tillage (NT). 
Table 2. Species composition of weeds per $1 \mathrm{~m}^{2}$ in soybean crop depending on the cropping system and tillage system (mean for 2014-2017).

\begin{tabular}{|c|c|c|c|c|}
\hline \multirow{2}{*}{ Species } & \multicolumn{2}{|c|}{ Cropping System } & \multicolumn{2}{|c|}{ Tillage System } \\
\hline & CR & $\mathrm{CM}$ & $\mathrm{CT}$ & NT \\
\hline \multicolumn{5}{|c|}{ I. Short-lived } \\
\hline Amaranthus retroflexus L. & $3.4 \mathrm{a}$ & $7.3 b$ & $4.5 \mathrm{a}$ & $6.1 \mathrm{a}$ \\
\hline Anagallis arvensis L. & $0.1 \mathrm{a}$ & $0.1 \mathrm{a}$ & $0.1 \mathrm{a}$ & $0.1 \mathrm{a}$ \\
\hline Anchusa arvensis (L.) M. Bieb. & $0.3 a$ & - & - & $0.3 a$ \\
\hline Avena fatua $\mathrm{L}$ & $1.5 \mathrm{a}$ & $2.8 \mathrm{~b}$ & $1.4 \mathrm{a}$ & $2.9 \mathrm{~b}$ \\
\hline Capsella bursa-pastoris (L.) Medik. & $0.8 \mathrm{a}$ & $1.2 \mathrm{a}$ & $1.2 \mathrm{a}$ & $0.9 \mathrm{a}$ \\
\hline Chenopodium album L. & $0.8 \mathrm{a}$ & $3.6 b$ & $2.2 \mathrm{a}$ & $2.2 \mathrm{a}$ \\
\hline Echinochloa crus-galli (L.) P. Beauv. & $4.2 \mathrm{a}$ & $2.5 \mathrm{a}$ & $3.1 \mathrm{a}$ & $3.7 \mathrm{a}$ \\
\hline Euphorbia helioscopia L. & - & $0.2 \mathrm{a}$ & $0.1 \mathrm{a}$ & $0.2 \mathrm{a}$ \\
\hline Fallopia convolvulus (L.) Á. Löve & $0.6 a$ & $0.3 \mathrm{a}$ & $0.4 \mathrm{a}$ & $0.6 \mathrm{a}$ \\
\hline Galium aparine L. & $0.8 \mathrm{a}$ & $0.2 \mathrm{a}$ & $0.4 \mathrm{a}$ & $0.6 \mathrm{a}$ \\
\hline Lamium amplexicaule $\mathrm{L}$. & $0.1 \mathrm{a}$ & $0.2 \mathrm{a}$ & $0.2 \mathrm{a}$ & $0.1 \mathrm{a}$ \\
\hline Matricaria maritima ssp. inodora (L.) Dostál & $0.5 \mathrm{a}$ & $1.2 \mathrm{a}$ & $0.6 a$ & $1.2 \mathrm{a}$ \\
\hline Melandrium album (Mill.) Garcke & $0.2 \mathrm{a}$ & $0.2 \mathrm{a}$ & $0.1 \mathrm{a}$ & $0.2 \mathrm{a}$ \\
\hline Polygonum aviculare L. & $1.6 a$ & $1.8 \mathrm{a}$ & $1.9 \mathrm{a}$ & $1.4 \mathrm{a}$ \\
\hline Solanum nigrum L. Emend. Mill. & $0.4 \mathrm{a}$ & $2.0 \mathrm{~b}$ & $0.5 \mathrm{a}$ & $1.9 \mathrm{~b}$ \\
\hline Sonchus asper (L.) Hill. & $0.6 a$ & $0.5 \mathrm{a}$ & $0.4 \mathrm{a}$ & $0.6 \mathrm{a}$ \\
\hline Stellaria media (L.) Vill. & $0.3 a$ & $0.4 \mathrm{a}$ & $0.3 \mathrm{a}$ & $0.4 \mathrm{a}$ \\
\hline Thlaspi arvense L. & - & $0.1 \mathrm{a}$ & $0.1 \mathrm{a}$ & - \\
\hline Veronica persica Poir. & $0.1 \mathrm{a}$ & - & - & $0.1 \mathrm{a}$ \\
\hline Viola arvensis Murr. & $0.3 a$ & - & $0.2 \mathrm{a}$ & $0.1 \mathrm{a}$ \\
\hline \multicolumn{5}{|l|}{ II. Perennial } \\
\hline Cirsium arvense (L.) Scop. & $0.3 a$ & $1.0 \mathrm{a}$ & $0.5 \mathrm{a}$ & $0.7 \mathrm{a}$ \\
\hline Convolvulus arvensis L. & $0.1 \mathrm{a}$ & - & - & $0.1 \mathrm{a}$ \\
\hline Elymus repens (L.) Gould & $0.1 \mathrm{a}$ & $3.4 b$ & $0.8 \mathrm{a}$ & $2.7 \mathrm{a}$ \\
\hline Plantago major L. & - & $0.2 \mathrm{a}$ & $0.1 \mathrm{a}$ & $0.1 \mathrm{a}$ \\
\hline Sonchus arvensis L. & $0.2 \mathrm{a}$ & $0.1 \mathrm{a}$ & $0.1 \mathrm{a}$ & $0.2 \mathrm{a}$ \\
\hline Number of weed species & $22 a$ & $21 \mathrm{a}$ & $22 a$ & $24 a$ \\
\hline
\end{tabular}

$\mathrm{CR}$-crop rotation, $\mathrm{CM}-$ monoculture, $\mathrm{CT}-$ plough tillage, NT-no-tillage. Different letters denote significant differences $(p \leq 0.05)$ of the number of weed species among different cropping systems $(C R$ and $C M)$ and tillage systems (CT and NT). The same letter means it is not significantly different.

A total of 22 weed species occurred in the soybean crop grown under conventional tillage (CT), whereas, in the no-tillage (NT) treatment, 24 species occurred (Table 2). Anchusa arvensis, Veronica persica, and the perennial species Convolvulus arvensis were found in the NT treatment, but they did not infest soybeans grown under the conventional system. In the CT treatment, on the other hand, the species Thlaspi arvense was observed, which was not found in the NT treatment. Amaranthus retroflexus occurred in the greatest numbers in both tillage systems. In the NT treatment, the number of Avena fatua and Solanum nigrum significantly increased compared to CT.

In crop rotation, 22 weed species were found under no-tillage conditions, while, in the conventional tillage treatment, there were six fewer species (Table 3). The following annual weeds: Anchusa arvensis, Lamium amplexicaule, Veronica persica, and perennial weeds: Convolvulus arvensis, Elymus repens, Sonchus arvensis, did not occur in soybeans grown in crop rotation under CT, but they were found in the non-tilled plots. In the soybean monoculture, greater weed species' richness (21 species) was observed in the CT treatment where Lamium amplexicaule, Thlaspi arvense, and Sonchus arvensis were found to be present, which are species that did not occur in the non-tilled plots (NT). Both in crop rotation and soybean monoculture, conventional tillage slightly reduced the number of the most numerous weed species. In crop rotation under CT conditions, the number of individuals of the dominant taxon, Echinochloa crus-galli, was $25.0 \%$ lower than under no-tillage (NT). However, these differences were 
not statistically significant. In the soybean crop grown in the monoculture, conventional tillage (CT) slightly reduced the number of individuals of the most numerous species, Amaranthus retroflexus.

Table 3. Interactive dependencies of the cropping system and tillage system in shaping weed species' composition per $1 \mathrm{~m}^{2}$ in soybean crops (mean for 2014-2017).

\begin{tabular}{|c|c|c|c|c|}
\hline Species & CR_CT & CR_NT & CM_CT & CM_NT \\
\hline \multicolumn{5}{|c|}{ I. Short-lived } \\
\hline Amaranthus retroflexus L. & $3.2 \mathrm{a}$ & $3.6 a$ & $5.9 \mathrm{a}$ & $8.7 \mathrm{a}$ \\
\hline Anagallis arvensis L. & $0.1 \mathrm{a}$ & $0.1 \mathrm{a}$ & $0.1 \mathrm{a}$ & $0.1 \mathrm{a}$ \\
\hline Anchusa arvensis (L.) M. Bieb. & - & $0.7 \mathrm{a}$ & - & - \\
\hline Avena fatua L. & $1.2 \mathrm{a}$ & $1.8 \mathrm{a}$ & $1.5 \mathrm{a}$ & $4.1 \mathrm{a}$ \\
\hline Capsella bursa-pastoris (L.) Medik. & $1.0 \mathrm{a}$ & $0.6 \mathrm{a}$ & $1.3 \mathrm{a}$ & $1.2 \mathrm{a}$ \\
\hline Chenopodium album $\mathrm{L}$. & $0.6 \mathrm{a}$ & $1.0 \mathrm{a}$ & $3.8 \mathrm{a}$ & $3.3 \mathrm{a}$ \\
\hline Echinochloa crus-galli (L.) P. Beauv. & $3.6 a$ & $4.8 \mathrm{a}$ & $2.5 \mathrm{a}$ & $2.5 \mathrm{a}$ \\
\hline Euphorbia helioscopia L. & - & - & $0.1 \mathrm{a}$ & $0.3 a$ \\
\hline Fallopia convolvulus (L.) Á. Löve & $0.5 \mathrm{a}$ & $0.7 \mathrm{a}$ & $0.2 \mathrm{a}$ & $0.4 \mathrm{a}$ \\
\hline Galium aparine L. & $0.5 a$ & $1.1 \mathrm{a}$ & $0.2 \mathrm{a}$ & $0.2 \mathrm{a}$ \\
\hline Lamium amplexicaule $\mathrm{L}$. & - & $0.2 \mathrm{a}$ & $0.5 a$ & - \\
\hline Matricaria maritima ssp. inodora (L.) Dostál & $0.4 \mathrm{a}$ & $0.6 a$ & $0.8 \mathrm{a}$ & $1.7 \mathrm{a}$ \\
\hline Melandrium album (Mill.) Garcke & $0.1 \mathrm{a}$ & $0.2 \mathrm{a}$ & $0.2 \mathrm{a}$ & $0.2 \mathrm{a}$ \\
\hline Polygonum aviculare L. & $1.8 \mathrm{a}$ & $1.3 \mathrm{a}$ & $2.0 \mathrm{a}$ & $1.5 \mathrm{a}$ \\
\hline Solanum nigrum L. Emend. Mill. & $0.5 \mathrm{a}$ & $0.4 \mathrm{a}$ & $0.5 \mathrm{a}$ & $3.4 b$ \\
\hline Sonchus asper (L.) Hill. & $0.4 \mathrm{a}$ & $0.7 \mathrm{a}$ & $0.5 \mathrm{a}$ & $0.6 \mathrm{a}$ \\
\hline Stellaria media (L.) Vill. & $0.3 a$ & $0.4 \mathrm{a}$ & $0.4 \mathrm{a}$ & $0.4 \mathrm{a}$ \\
\hline Thlaspi arvense L. & - & - & $0.2 \mathrm{a}$ & - \\
\hline Veronica persica Poir. & - & $0.2 \mathrm{a}$ & - & - \\
\hline Viola arvensis Murr. & $0.4 \mathrm{a}$ & $0.2 \mathrm{a}$ & - & - \\
\hline \multicolumn{5}{|c|}{ II. Perennial } \\
\hline Cirsium arvense (L.) Scop. & $0.1 \mathrm{a}$ & $0.5 \mathrm{a}$ & $1.0 \mathrm{a}$ & $1.0 \mathrm{a}$ \\
\hline Convolvulus arvensis L. & - & $0.2 \mathrm{a}$ & - & - \\
\hline Elymus repens (L.) Gould & - & $0.2 \mathrm{a}$ & $1.7 \mathrm{a}$ & $5.1 \mathrm{a}$ \\
\hline Plantago major L. & - & - & $0.1 \mathrm{a}$ & $0.2 \mathrm{a}$ \\
\hline Sonchus arvensis L. & - & $0.3 \mathrm{a}$ & $0.1 \mathrm{a}$ & - \\
\hline
\end{tabular}

CR_CT—crop rotation and plough tillage, CR_NT—crop rotation and no-tillage, CM_CT—monoculture and plough tillage, CM_NT-monoculture and no-tillage. Different letters denote significant differences $(p \leq 0.05)$ of the number of weed species for an interaction among crop rotation (CR), monoculture (CM), plough tillage (CT), and no-tillage (NT).

The evaluation of the biological diversity of the segetal flora showed that the Shannon-Wiener index $\left(\mathrm{H}^{\prime}\right)$ and the Simpson index (SI) did not differ significantly in crop rotation (CR) and a soybean monoculture (CM). The soybean crop grown in the no-tillage (NT) system was characterized by slightly greater diversity of the weed community than under CT. This is indicated by the higher value of the Shannon diversity index and a slightly lower value of the Simpson dominance index (Figure 9).

The interaction of the cropping system and tillage system did not cause significant variations in the Shannon-Wiener diversity index and the Simpson dominance index (Figure 10). The agrophytocenosis of the soybean crop grown in crop rotation in the NT treatment was characterized by the greatest diversity, while the lowest one was found in the case of crop rotation and CT conditions. Nonetheless, the difference in the values of the diversity and dominance indices between the individual treatments was not significant. 


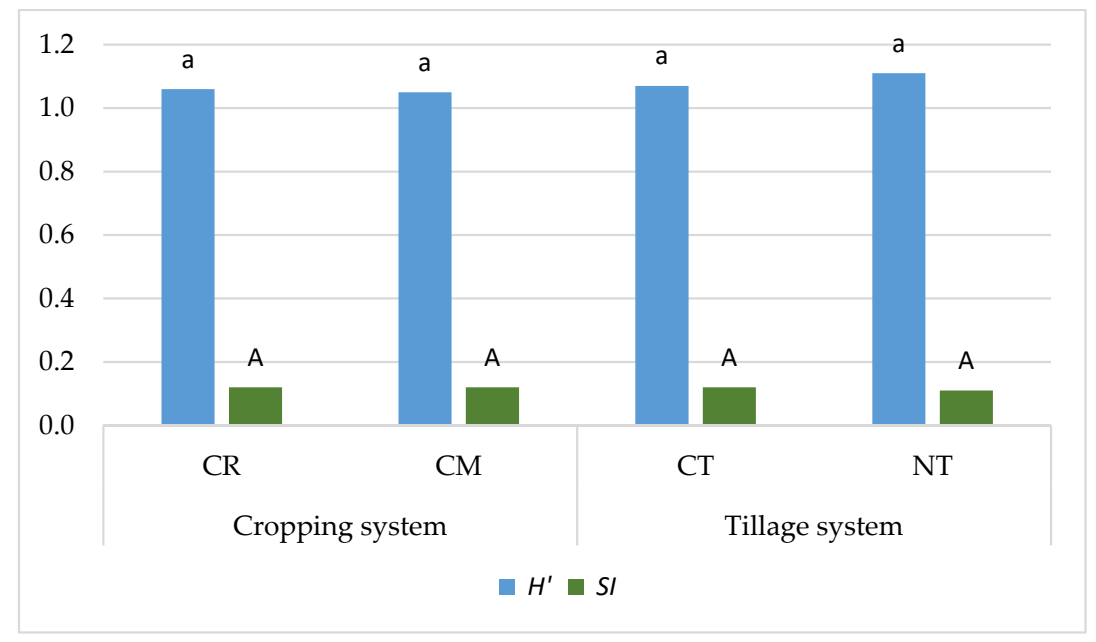

Figure 9. Shannon-Wiener's diversity index $\left(H^{\prime}\right)$ and Simpson's dominance index $(S I)$ of the weed community in soybean crop depending on the cropping system and tillage system (mean for 2014-2017). $\mathrm{CR}$-crop rotation, $\mathrm{CM}$ - monoculture, CT—plough tillage, and NT—no-tillage. Different lowercase letters denote significant differences $(p \leq 0.05)$ of Shannon-Wiener's diversity index $\left(H^{\prime}\right)$ among different cropping systems (CR and CM) and tillage systems (CT and NT). Different capital letters denote significant differences $(p \leq 0.05)$ of Simpson's dominance index (SI) among different cropping systems (CR and CM) and tillage systems (CT and NT).

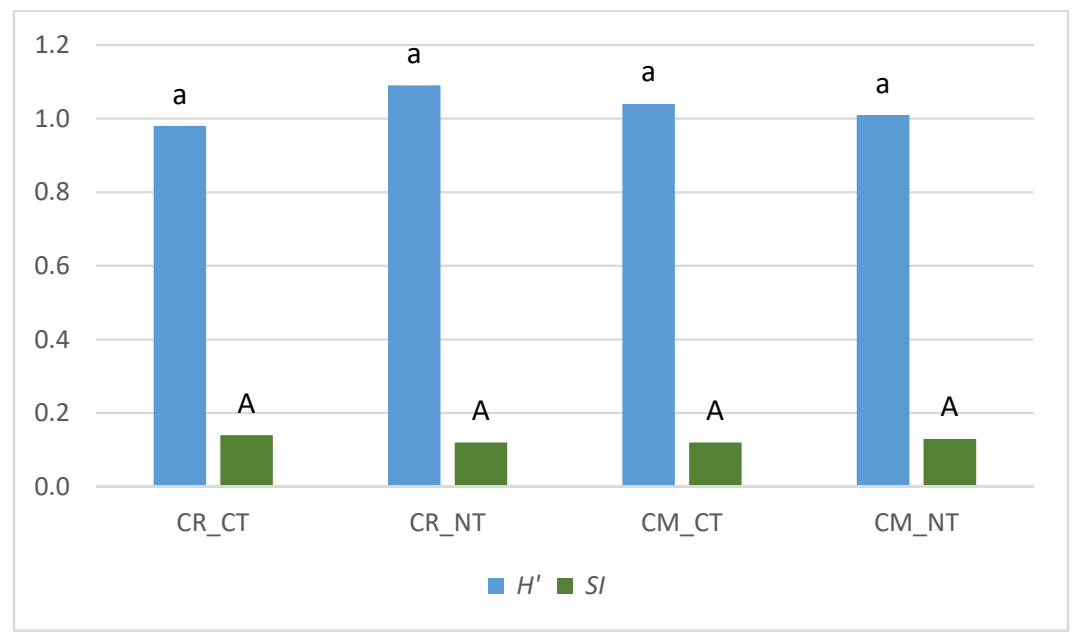

Figure 10. Interactive dependencies of the cropping system and tillage system in shaping Shannon-Wiener's diversity index $\left(H^{\prime}\right)$ and Simpson's dominance index $(S I)$ of the weed community in soybean crop (mean for 2014-2017). CR_CT—crop rotation and plough tillage, CR_NT—crop rotation and no-tillage, CM_CT-monoculture and plough tillage, CM_NT_monoculture and no-tillage. Different lowercase letters denote significant differences $(p \leq 0.05)$ of Shannon-Wiener's diversity index $\left(H^{\prime}\right)$ for interaction among crop rotation, monoculture, plough tillage $(\mathrm{CT})$, and no-tillage (NT). Different capital letters denote significant differences $(p \leq 0.05)$ of Simpson's dominance index (SI) for an interaction among crop rotation $(\mathrm{CR})$, monoculture $(\mathrm{CM})$, plough tillage $(\mathrm{CT})$, and no-tillage (NT).

\subsection{Infection of Soybean Plants with Diseases}

In every year of the study, soybeans were infected with Ascochyta blight (Ascochyta sp.), Septoria leaf spot (Septoria glycines), and frogeye leaf spot (Cercospora sojina). The severity of diseases observed was dependent on the factors studied, but it was generally low in the 2015 growing season characterized by the lowest rainfall level. The growing seasons in 2014 and 2017, during which the 
highest amount of rainfall was recorded, promoted the growth of fungal pathogens. During these seasons, infection of soybean with Ascochyta blight, Septoria leaf spot, and frogeye leaf spot was found to be the highest. In 2017, the severity of symptoms of all diseases observed was significantly higher than in 2015 and 2016. Soybean plants were infected with the pathogen Septoria glycines to the greatest degree, which was followed by Cercospora sojina, while infection with Ascochyta sp. Was the lowest (Figures 11-13).

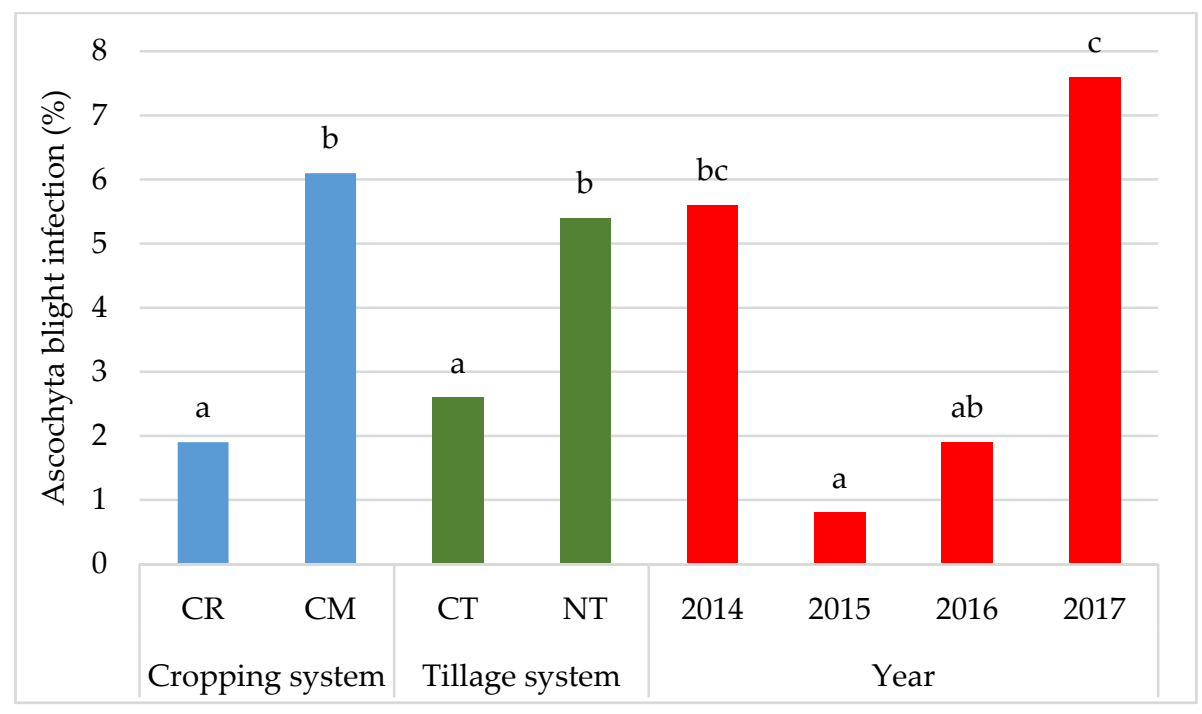

Figure 11. Mean infection of soybean with Ascochyta blight (Ascochyta sp.) depending on the cropping system, tillage system, and years of research. CR—crop rotation, $\mathrm{CM}-$ monoculture, $\mathrm{CT}-$ plough tillage, NT-no-tillage. Different letters denote significant differences $(p \leq 0.05)$ among different cropping systems (CR and CM), tillage systems (CT and NT), and years of research. The same letter means it is not significantly different.

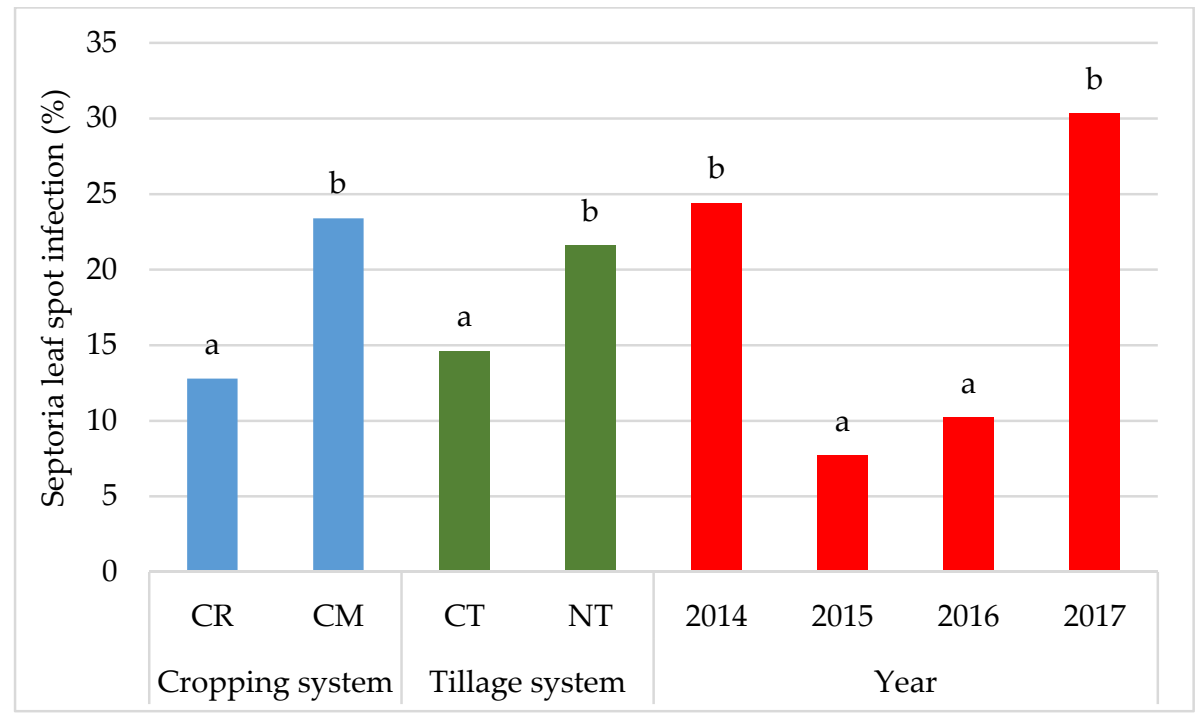

Figure 12. Mean infection of soybeans with Septoria leaf spot (Septoria glicynes) depending on the cropping system, tillage system, and years of research. CR-crop rotation, $\mathrm{CM}-$ monoculture, CT-plough tillage, NT—no-tillage. Different letters denote significant differences $(p \leq 0.05)$ among different cropping systems (CR and CM), tillage systems (CT and NT), and years of research. The same letter means it is not significantly different. 


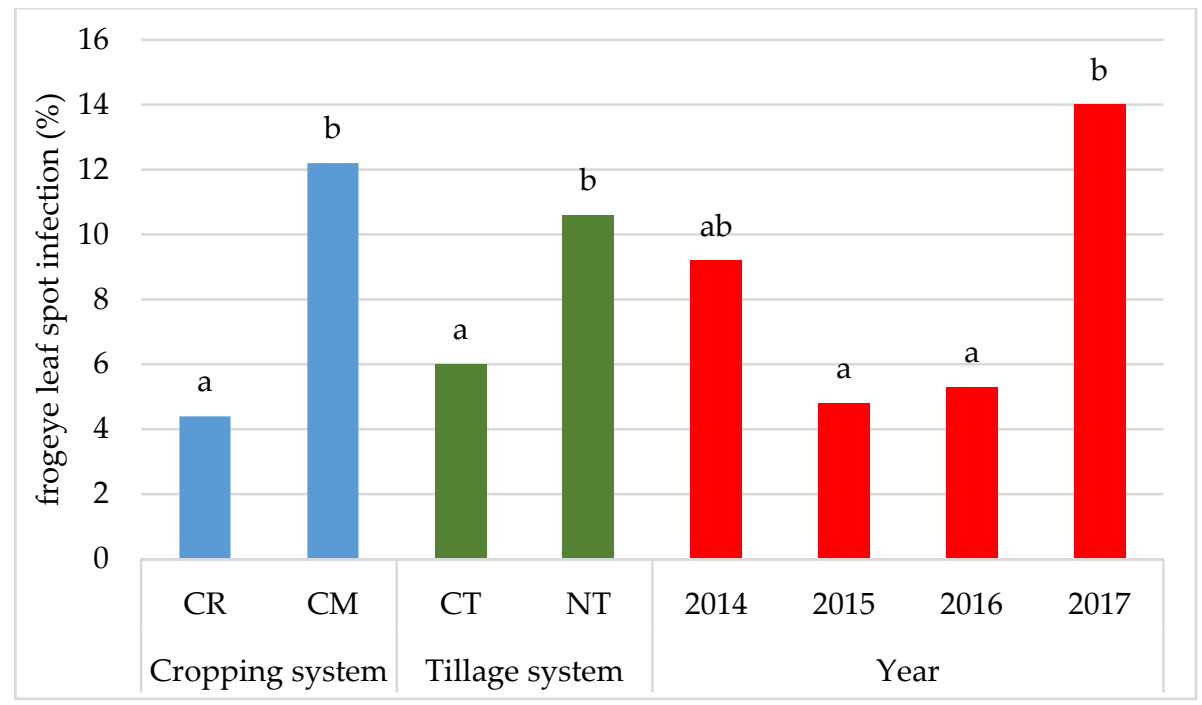

Figure 13. Mean infection of soybeans with frogeye leaf spot (Cercospora sojina) depending on the cropping system, tillage system, and years of study. CR—crop rotation, $\mathrm{CM}-$ monoculture, $\mathrm{CT}$ - plough tillage, NT-no-tillage. Different letters denote significant differences $(p \leq 0.05)$ among different cropping systems (CR and CM), tillage systems (CT and NT), and years of research. The same letter means being not significantly different.

On average, over the four-year study period, the experimental factors were proven to influence the health of soybean plants (Figures 11-13). In the monoculture, the severity of infection with the pathogens causing Ascochyta blight, Septoria leaf spot, and frogeye leaf spot was higher by, respectively, more than three times, almost two times, and nearly three times when compared to crop rotation. The no-tillage system promoted the severity of all soybean diseases observed in this experiment. It was proven that, under the CT system, plant infection by the pathogens Ascochyta sp., Septoria glycines, and Cercospora sojina was lower by $51.9 \%, 32.4 \%$, and $43.4 \%$, respectively, than under no-tillage (NT).

\section{Discussion}

Weeds are strong competitors for soybeans. With heavy weed infestation, plants exhibit nutrient deficiency symptoms and are pale green, while seed yield is lower and of worse quality. Therefore, the profitability of cultivation of this legume crop is greatly dependent on effective elimination of weed infestation [2]. Weed infestation of crops can be effectively reduced, among others, by selecting an appropriate position of a given crop in crop rotation [26]. The study presented in this paper proved that growing soybeans after winter wheat as a previous crop reduces weed infestation when compared to what was determined in the monoculture. The results of a study by Cardina et al. [27] reveal that monoculture cropping promotes the accumulation of weed seeds in the soil. In the study of these authors, the number of weed seeds was also affected by the interaction between tillage and crop rotation since the highest seed density was shown in the monoculture under NT conditions. Our research did not prove the interaction between the cropping system and tillage system impacted weed infestation of the soybean crop, but a slightly higher number of weeds was observed in the soybean monoculture under NT conditions when compared to that found in the other experimental treatments.

The results of studies regarding the effect of tillage systems on weed infestation of crops are not unequivocal. Santín-Montanyá et al. [28] did not prove conventional tillage and no-tillage systems to have a significant impact on the number of weeds in the winter wheat crop. However, the results of these authors' research, similarly to those presented in our paper, show that weed community diversity, as expressed by the Shannon index, increased under the NT system. Sebayang and Rifai [18], on the other hand, found that the dry weed weight in the soybean crop did not differ significantly between conventional tillage, reduced tillage, and no-tillage. Nonetheless, many authors point out that the 
no-tillage system increases weed infestation of crops [29-32]. Our experiment also demonstrated a significant increase in the number and weight of weeds under the NT system in comparison with CT. Such an increase may be due to the accumulation of freshly shed weed seeds in the topsoil layer where they germinate and sprout in great numbers in the succeeding crop [33-35]. As a matter of fact, the tillage system does not affect the seed bank size but changes both the composition and distribution of diaspores in the soil profile [36]. The study by Cardina et al. [27] revealed that the number of weed seeds in the soil was highest under NT and generally decreased with increasing tillage intensity. These authors also proved that, under the NT system, weed seeds accumulated near the soil surface (from 0 to $5 \mathrm{~cm}$ ) whereas, under the other tillage systems, they were evenly distributed across the entire tilled layer. In the opinion of Małecka et al. [37], increased weed infestation under the NT system can generally be observed in the first crop rotation cycle, whereas, during the subsequent period, weed infestation stabilizes and even some positive aspects of no-till field preparation are noticeable.

In the opinion of Chovancova et al. [38], Małecka-Jankowiak et al. [39], and Mancinelli et al. [40], the tillage system modifies soil properties, and, thus, affects plant growth and development. Its effect can be a change in the species' composition of weeds growing in a crop, as shown, among others, by the research presented in this paper. Velykis and Satkus [41] also proved that no-tillage caused a change in the weed species' composition in comparison with the conventional system. In particular, it increased the presence of Galium aparine and Chenopodium album in the cultivation of a legume crop (pea). According to Campiglia et al. [42], no-tillage can lead to increased occurrence of perennial weeds, which are difficult to control. This is confirmed by our study, which recorded increased numbers of the species Elymus repens under the NT system when compared to CT.

From the beginnings of agriculture development, weed control has been carried out using various practices such as soil tillage or crop rotation, while, in recent years, crop protection products have also been used. Widespread application of herbicides has deeply modified agro-ecosystems, negatively affecting their species' diversity and causing herbicide resistance to occur, which has resulted in the appearance of the superweeds, that is, weeds resistant to glyphosate $[43,44]$. This threatens many functions of an ecosystem, which is of key importance for food production [43] because biodiversity in crop fields and their surroundings performs a number of biological functions in nutrient cycling and utilization as well as in the maintenance of balance among pathogens attacking crops $[45,46]$. Therefore, the aim of international policy and conducted research has become biodiversity conservation, including the species diversity of agroecosystems [47,48]. According to Clements et al. [49], if diversity increases and the number of ecological interactions also increases, weed species should be viewed as an interactive community rather than an unrelated set of targets for control. The study presented in our paper demonstrates that the NT positively influences the weed community diversity in the soybean crop relative to the CT system. However, no changes were found in the diversity of segetal flora depending on the cropping system. On the other hand, a study by Suwary et al. [50] proved that monoculture cropping contributes to decreased weed species' diversity. Under conditions of winter wheat monoculture cropping, Sekutowski and Domaradzki [51] found a greater dominance of weeds and, at the same time, lower weed species' biodiversity as a result of using tillage reductions.

Weeds occurring in a crop contribute to a change in thermal and moisture conditions in it, which, thus, creates favorable conditions for developing many fungal pathogens [52]. Unwanted vegetation can be an indirect host for pathogenic fungi and contribute to the spread of diseases and greater infection of the crop [53-55]. Our research is also a confirmation of these theories because, in the present study, an increased incidence of fungal diseases was found in the treatments with the highest number and dry weight of weeds. Given the above, it is very important to timely and effectively eliminate weeds as a potential reservoir of fungal diseases [56]. Some biologically active substances used to control weed infestation can also contribute to reducing fungal diseases of soybeans. Plenty of attention has been devoted to glyphosate, which is a commonly used active substance. It results in reduced germination of spores of the fungus Phakopsora pachyrhizi, which causes soybean rust and leads to a lower incidence of this disease in plants $[57,58]$. Application of lactofen and sulfentrazone promotes 
increased production of phytoalexin in leaves, which is a substance that inhibits the occurrence of Sclerotinia sclerotiorum in soybeans $[59,60]$. It should, however, be indicated that lactofen can cause minor transient damage to the crop plant [61] through which pathogens can easily penetrate into the plant [62]. In the literature, reports can be found that, among others, glyphosate application leads to increased numbers of fungi and disturbances in soil biological balance [63]. Crops are then more susceptible to infection by diverse fungal pathogens [64].

Symptoms of many diseases caused by fungi can be observed in soybeans, but, under Polish conditions, these diseases have not been economically important so far. It is also rarely necessary to use fungicides [2]. In our study, soybeans were infected with Septoria leaf spot (Septoria glycines) and frogeye leaf spot (Cercospora sojina). Soybeans were infected to the lowest degree with Ascochyta blight (Ascochyta sp.). Nonetheless, Amin and Melkamu [65], Bretag et al. [66], Davidson and Kimber [67] as well as Sudheesh et al. [68] have shown that the fungus Ascochyta sp. can pose a major threat to legume crops and cause a significant loss in yields.

The severity of infection of plants with fungal diseases is largely associated with weather conditions in a particular growing season. Both our research and the studies of other authors reveal that years characterized by a high amount of rainfall most favor the development of fungal diseases $[69,70]$. In our research in thermal terms, the years 2015 and 2017 proved to be unfavorable for soybean development (Figures 1 and 2). In 2015, in the sowing month and during the initial growth of soybeans (May), when its thermal requirements are very high, a lower temperature was recorded when compared to the long-term mean. The lowest rainfall level was noted in the second growing season (2015), which significantly contributed to reduced weed infestation and decreased infection of soybeans with fungal diseases. The highest rainfall was observed in 2014 and 2017. The year 2017 was unfavorable for soybean development, predominantly in terms of rainfall distribution. There was a rainfall deficit in June (flowering stage), while, in July (flowering/seed filling) and in September, excessive rainfall was recorded. Such a distribution of precipitation favored the development of fungal diseases. In 2017, a lower temperature was observed in April than in the other years of the study when compared to the long-term mean. Due to this and because of torrential rains, sowing of soybeans was done in the first 10 days of May.

Numerous studies, including the study presented in this paper, have proven that monoculture cropping contributes to increased infection of plants with fungal diseases [17,70]. Strom et al. [71] demonstrated that long-term corn and soybean monoculture was associated with substantial changes in fungal communities and their distribution, as the number of host-specific fungal pathogens increased.

In the studies by Kraska et al. [72] and Suproniene et al. [73], tillage systems did not cause differences in infection of wheat by a complex of fungal diseases. The results of our experiment, however, show that the no-tillage system is conducive to the increased prevalence of fungal diseases of soybeans. Vrandečić et al. [74] also proved that fungal infection of soybeans is much higher under reduced tillage and no-tillage conditions compared to that found under conventional tillage. According to these authors, the amount and intensity of rainfall and temperature were the most important factors influencing the level of infection.

The research presented in this paper demonstrates that the no-tillage system and monoculture cropping promoted weed infestation and infection of soybeans with fungal diseases when compared to the conventional tillage system and crop rotation. The results on soybean yield reported in a paper by Gawęda et al. [75] proved that the seed yields in the experiment in question were much lower in the no-tillage treatment. A decreasing trend in yield in a soybean monoculture was observed as late as the fourth year of the experiment [75]. It was also found that infection of soybeans with fungal diseases was greatest in 2020. A high number of weeds and the dry weight of weeds were also recorded. 


\section{Conclusions}

1. The cultivation of the soybean after it promotes weed infestation. The number and dry weight of weeds was proven to be higher in the monoculture $(\mathrm{CM})$ than in crop rotation $(\mathrm{CR})$, respectively, by $69.4 \%$ and $28.6 \%$.

2. Under no-tillage (NT), the number of weeds and dry weight of weeds was, respectively, higher by $42.7 \%$ and $36.8 \%$ than under conventional tillage (CT).

3. The statistical analysis confirmed that growing soybeans in crop rotation, compared to the monoculture, and, in the no-tillage system, increases the percentage of monocotyledonous species in total dry weight of weeds.

4. In crop rotation, Echinochloa crus-galli was the most numerous weeds in the soybean crop, whereas, in a monoculture, it was Amaranthus retroflexus. Reducing the numbers of Amaranthus retroflexus, Chenopodium album, Avena fatua, Solanum nigrum, and Elymus repens was observed in crop rotation.

5. In both tillage systems, Amaranthus retroflexus was the weed species that occurred in the greatest numbers in the soybean crop. A significantly lower number of Avena fatua and Solanum nigrum was found under conventional tillage (CT) when compared to no-tillage (NT).

6. Cropping systems and tillage systems only slightly changed the biological diversity of the weed community in the soybean crop. The Shannon-Wiener index $\left(H^{\prime}\right)$ and the Simpson index (SI) were shown to have similar values in crop rotation $(\mathrm{CR})$ and the soybean monoculture $(\mathrm{CM})$, whereas the biological diversity of the weed community was found to be only slightly greater under the NT system compared to the CT system.

7. Throughout the study period, soybeans were infected with Ascochyta blight (Ascochyta sp.), Septoria leaf spot (Septoria glycines), and frogeye leaf spot (Cercospora sojina). The severity of disease symptoms in most of the growing seasons was greater in the seasons characterized by a high amount of rainfall.

8. Soybean plants were most infected with the pathogen Septoria glycines and least infected with Ascochyta sp.

9. No-tillage and monoculture cropping promoted infection of soybeans with fungal diseases in comparison to the conventional system and crop rotation.

Author Contributions: The authors contributed to this article in the following ways: Conceptualization: D.G. Data curation, D.G. and J.Ł. Formal analysis: D.G., M.H., and U.B.-M. Investigation: D.G. and M.H. Supervision: D.G. and M.H. Visualization: D.G. and U.B.-M. Writing-original draft: D.G. and M.H. Writing-review and editing: D.G. M.H. and J.Ł. All authors have read and agreed to the published version of the manuscript.

Funding: The Ministry of Science and Higher Education of Poland as part of statutory activities of Department of Herbology and Plant Cultivation Techniques, University of Life Sciences in Lublin, funded this research.

Conflicts of Interest: The authors declare no conflict of interest.

\section{References}

1. Abbasi Surki, A.; Sharifzade, F.; Tavakkol Afshari, R.; Majnoun Hosseini, N.; Gazor, H.R. Optimization of processing parameters of soybean seeds dried in a constant-bed dryer using response surface methodology. J. Agric. Sci. Tech. Iran. 2010, 12, 409-423.

2. Filoda, G.; Mrówczyński, M.; Matyjaszczyk, E.; Kierzek, R.; Nawracała, J.; Bubniewicz, P.; Fiedler, Ż.; Kornobis, F.; Matysiak, K.; Pruszyński, G.; et al. Metodyka Integrowanej Ochrony i Produkcji Soi Dla Doradców; Instytut Ochrony Roślin-Państwowy Instytut Badawczy: Poznań, Poland, 2016. (In Polish)

3. The Act of March 8, 2013 on Crop Protection Products (Dz. U. (Journal of Laws) Item 455, 505. Available online: https://www.gov.pl/web/rolnictwo/akty-prawne3 (accessed on 28 April 2020). (In Polish)

4. Anderson, R.L. Impact of subsurface tillage on weed dynamics in the Central Grein Plains. Weed Tech. 2004, 18, 186-192. [CrossRef]

5. Chokor, J.U.; Ikuenobe, C.E.; Akaelu, I.A. The Effect of tillage and herbicides (rimsulfuron and codal gold) on weed regeneration. Inter. J. Soil Sci. 2008, 3, 164-168. [CrossRef] 
6. Gruber, S.; Pekrun, C.; Möhring, J.; Claupein, W. Long-term yield and weed response to conservation and stubble tillage in SW Germany. Soil Till. Res. 2012, 121, 49-56. [CrossRef]

7. Morris, N.L.; Miller, P.C.H.; Orson, J.H.; Froud-Williams, R.J. The adoption of noninversion tillage systems in the United Kingdom and the agronomic impact on soil, crops and the environment-A review. Soil Till. Res. 2010, 108, 1-15. [CrossRef]

8. Jug, I.; Jug, D.; Sabo, M.; Bojan, S. Winter wheat yield and yield components as affected by soil tillage systems. Turk. J. Agric. For. 2011, 35, 1-7.

9. Jordan, V.W.L.; Hutcheon, J.A. Influence of Cultivation Practices on Arable Crop Diseases. In Soil Tillage in Agroecosystems; El-Titi, A., Ed.; CRC Press: Boca Raton, FL, USA, 2003; pp. 187-207.

10. Poštić's, J.; Cosic, J.; Vrandecic, K.; Jurkovic's, D.; Saleh, A.A.; Leslie, J.F. Diversity of Fusarium species isolated from weeds and plant debris in Croatia. J. Phytopathol. 2012, 160, 76-81. [CrossRef]

11. Perez-Brandan, C.; Arzeno, J.L.; Huidobro, J.; Grümberg, B.; Conforto, C.; Hilton, S.; Bending, G.D.; Meriles, J.M.; Vargas-Gil, S. Long term effect of tillage systems on soil microbiological, chemical and physical parameters and the incidence of charcoal rot by Macrophomina phaseolina (Tassi) Goid in soybean. Crop Prot. 2012, 40, 73-82. [CrossRef]

12. Ohnishi, S.; Miyoshi, T.; Shirai, S. Low temperature stress at different flower developmental stages affects pollen development, pollination, and pod set in soybean. Environ. Exp. Bot. 2010, 69, 56-62. [CrossRef]

13. Vollmann, J.; Winkler, J.; Fritz, C.N.; Grausgruber, H.; Ruckenbauer, P. Spatial field variations in soybean (Glycine max [L.] Merr.) performance trials affect agronomic characters and seed composition. Eur. J. Agron. 2000, 12, 13-22. [CrossRef]

14. Pittelkow, C.M.; Linquist, B.A.; Lundy, M.E.; Liang, X.; Van Groenigen, K.J.; Lee, J.; Van Gestel, N.; Six, J.; Venterea, R.T.; Van Kessel, C. When does no-till yield more? A global meta-analysis. Field Crops Res. 2015, 183, 156-168. [CrossRef]

15. Balota, E.L.; Kanashiro, M.; Filho, A.C.; Andrade, D.S.; Dick, R.P. Soil enzyme activities under long-term tillage and crop rotation systems in subtropical agroecosystems. Braz. J. Microbiol. 2004, 35, 300-306. [CrossRef]

16. Maillard, É.; Angers, D.A.; Chantigny, M.; Lafond, J.; Pageau, D.; Rochette, P.; Lévesque, G.; Leclerc, M.L.; Parent, L.E. Greater accumulation of soil organic carbon after liquid dairy manure application under cereal-forage rotation than cereal monoculture. Agric. Ecosyst. Environ. 2016, 233, 171-178. [CrossRef]

17. Calzarano, F.; Stagnari, F.; D’Egidio, S.; Pagnani, G.; Galieni, A.; Di Marco, S.; Metruccio, E.G.; Pisante, M. Durum wheat quality, yield and sanitary status under conservation agriculture. Agriculture 2018, 8, 140. [CrossRef]

18. Sebayang, H.T.; Rifai, A.P. The effect of soil tillage system and weeding time on the growth of weed and yield of soybean (Glycine max (L.) Merril). J. Degrad. Min. Land Manag. 2018, 5, 1237-1243. [CrossRef]

19. Tillmann, M.; Von Tiedemann, A.; Winter, M. Crop rotation effects on incidence and diversity of Fusarium species colonizing stem bases and grains of winter wheat. J. Plant Dis. Protect. 2017, 124, 121-130. [CrossRef]

20. IUSS Working Group WRB. World Reference Base for Soil Resources 2014, update 2015. In International Soil Classification System for Naming Soils and Creating Legends for Soil Maps; World Soil Resources Reports; FAO: Rome, Italy, 2015; p. 106.

21. Mirek, Z.; Piękoś-Mirkowa, H.; Zając, A.; Zając, M. Flowering Plants and Pteridophytes of Poland a Checklist. In Krytyczna Lista Roślin Naczyniowych Polski. W.; Szafer Institute of Botany, Polish Akademy of Science: Kraków, Poland, 2002; p. 442.

22. Shannon, C.E. A mathematical theory of communications. Bell Syst. Tech. J. 1948, 27, 379-423. [CrossRef]

23. Simpson, E.H. Measurement of diversity. Nature 1949, 168, 668. [CrossRef]

24. Łacicowa, B. Metoda laboratoryjna szybkiej oceny odporności jecczmienia na Helminthosporium sativum. Biul. IHAR 1969, 3-4, 61-62. (In Polish)

25. Gomez, K.A.; Gomez, A.A. Statistical Procedures for Agricultural Research; John Wiley \& Sons: Hoboken, NJ, USA, 1984.

26. Gawęda, D.; Woźniak, A.; Harasim, E. Weed infestations of winter wheat depend on the forecrop and the tillage system. Acta Agrobot. 2018, 71, 1-9. [CrossRef]

27. Cardina, J.; Herms, C.P.; Doohan, D.J. Crop rotation and tillage system effects on weed seedbanks. Weed Sci. 2002, 50, 448-460. [CrossRef] 
28. Santín-Montanyá, M.I.; Martín-Lammerding, D.; Walter, I.; Zambrana, E.; Tenorio, J.L. Efects of tillage, crop systems and fertilization on weed abundance and diversity in 4-year dry land winter wheat. Eur. J Agron. 2013, 48, 43-49. [CrossRef]

29. Gawęda, D.; Haliniarz, M.; Cierpiała, R.; Klusek, I. Yield, Weed infestation and seed quality of soybean (Glycine max (L.) Merr.) under different tillage systems. Tarim Bilim. Derg. 2017, 23, 268-275.

30. Sebayang, H.T.; Fatimah, S. The effect of tillage systems and dosages of cow manure on weed and soybeans yield (Glycine max, Merrill). J. Degrad. Min. Land Manag. 2019, 7, 1959-1963. [CrossRef]

31. Woźniak, A.; Rachoń, L. Effect of tillage systems on pea crop infestation with weeds. Arch. Agron. Soil Sci. 2019, 65, 877-885. [CrossRef]

32. Woźniak, A.; Soroka, M. Effects of a 3-year reduced tillage on the yield and quality of grain and weed infestation of spring triticale (Triticosecale Wittmack). J. Plant Prod. 2014, 8, 231-242.

33. Mahmoodi, S.; Rahimi, A. The critical period of weed control in corn in Birjand region, Iran. Inter. J. Plant Prod. 2009, 3, 91-96.

34. Mohler, C.L.; Frisch, J.C.; McCulloch, C.E. Vertical movement of weed seed surrogates by tillage implements and natural processes. Soil Till. Res. 2006, 86, 110-122. [CrossRef]

35. Peigné, J.; Ball, B.C.; Roger-Estrade, J.; David, C. Is conservation tillage suitable for organic farming? A review. Soil Use Manag. 2007, 23, 129-144. [CrossRef]

36. Ruisi, P.; Frangipane, B.; Amato, G.; Badagliacca, G.; Di Miceli, G.; Plaia, A.; Giambalvo, D. Weed seedbank size and composition in a long-term tillage and crop sequence experiment. Weed Res. 2015, 55, 320-328. [CrossRef]

37. Małecka, I.; Blecharczyk, A.; Dobrzeniecki, T. Zachwaszczenie zbóż ozimych w zależności od systemu uprawy roli. Prog. Plant Prot. 2006, 46, 253-255. (In Polish)

38. Chovancova, S.; Illek, F.; Winkler, J. The effect of three tillage treatments on weed infestation in maize monoculture. Pak. J. Bot. 2020, 52, 697-701. [CrossRef]

39. Małecka-Jankowiak, I.; Blecharczyk, A.; Swędzrzyńska, D.; Sawinska, Z.; Piechota, T. The effect of long-term tillage systems on some soil properties and yield of pea (Pisum sativum L.). Acta Sci. Pol. Agric. 2016, 15, 37-50.

40. Mancinelli, R.; Muleo, R.; Marinari, S.; Radicetti, E. How Soil Ecological Intensification by Means of Cover Crops Affects Nitrogen Use Efficiency in Pepper Cultivation. Agriculture 2019, 9, 145. [CrossRef]

41. Velykis, A.; Satkus, A. Weed infestation and changes in field pea (Pisum sativum L.) yield as affected by reduced tillage of a clay loam soil. Zemdirbyste 2010, 97, 73-82.

42. Campiglia, E.; Radicetti, E.; Mancinelli, R. Floristic composition and species diversity of weed community after 10 years of different cropping systems and soil tillage in a Mediterranean environment. Weed Res. 2018, 58, 273-283. [CrossRef]

43. Dainese, M.; Martin, E.A.; Aizen, M.; Albrecht, M.; Bartomeus, I.; Bommarco, R.; Carvalheiro, L.G.; Chaplin-Kramer, R.; Gagic, V.; Garibaldi, L.A.; et al. A global synthesis reveals biodiversity-mediated benefits for crop production. Sci. Adv. 2019, 5, eaax0121. [CrossRef]

44. García, M.J.; Palma-Bautista, C.; Rojano-Delgado, A.M.; Bracamonte, E.; Portugal, J.; Alcántara-de la Cruz, R.; De Prado, R. The triple amino acid substitution TAP-IVS in the EPSPS gene confers high glyphosate resistance to the superweed Amaranthus hybridus. Int. J. Mol. Sci. 2019, 20, 2396. [CrossRef]

45. Altieri, M.A. The ecological role of biodiversity in agroecosystems. Agric. Ecosyst. Environ. 1999, 74, $19-31$. [CrossRef]

46. Feledyn-Szewczyk, B. Zmiany bioróżnorodności flory segetalnej w systemie ekologicznym w latach 1996-2007. Res. Appl. Agric. Eng. 2008, 53, 63-68. (In Polish)

47. Scholes, R.J.; Mace, G.M.; Turner, W.; Geller, G.N.; Jürgens, N.; Larigauderie, A.; Muchoney, D.; Walther, B.A.; Mooney, H.A. Toward a global biodiversity observing system. Science 2008, 321, 1044-1045. [CrossRef] [PubMed]

48. Rands, M.R.; Adams, W.M.; Bennun, L.; Butchart, S.H.; Clements, A.; Coomes, D.; Entwistle, A.; Hodge, I.; Kapos, V.; Scharlemann, J.P.; et al. Biodiversity conservation: Challenges beyond 2010. Science 2010, 329, 1298-1303. [CrossRef] [PubMed]

49. Clements, D.R.; Weise, R.; Swanton, C.J. Integrated weed management and weed species diversity. Phytoprotection 1994, 75, 1-18. [CrossRef] 
50. Suwara, I.; Stępień, W.; Tymińska, A.; Pruska, K. Wpływ wieloletniego nawożenia mineralnego i zmianowania na zachwaszczenie pszenżyta ozimego. Fragm. Agron. 2016, 33, 107-116. (In Polish)

51. Sekutowski, T.; Domaradzki, K. Bioróżnorodność gatunkowa chwastów w monokulturze pszenicy ozimej w warunkach stosowania uproszczeń w uprawie roli. Fragm. Agron. 2009, 26, 160-169. (In Polish)

52. Kim, S.I.; Toon, J.S.; Jung, J.W.; Hong, K.B.; Ahn, Y.J.; Kwon, H.W. Toxicity and repellency of origanum essential oil and its components against Tribolium castaneum (Coleoptera: Tenebrionidae) adults. J. Asia Pac. Entomol. 2010, 13, 369-373. [CrossRef]

53. Hepperly, P.R.; Kirkpatrick, B.L.; Sinclair, J.B. Abutilon theophrasti: Wild host for three fungal parasites of soybean. Phytopathology 1980, 70, 307-310. [CrossRef]

54. Srinivas, P.; Ramesh Babu, S.; Ratan, V. Role of sclerotia, plant debris and different hosts on survival of rice sheath blight pathogen, Rhizoctonia solani. Int. J. Appl Biol. Pharm. 2014, 5, 29-33.

55. Nagaraj, B.T.; Sunkad, G.; Pramesh, D.; Naik, M.K.; Patil, M.B. Host range studies of rice sheath blight fungus Rhizoctonia solani (Kuhn). Int. J. Curr. Microbiol. App. Sci. 2017, 6, 3856-3864. [CrossRef]

56. Chowdhury, A.; Pradhan, S.; Saha, M.; Sanyal, N. Impact of pesticides on soil microbiological parameters and possible bioremediation strategies. Ind. J. Microbiol. 2008, 48, 114-127. [CrossRef]

57. Feng, P.C.C.; Baley, G.J.; Clinton, W.P.; Bunkers, G.J.; Alibhai, M.F.; Paulitz, T.C.; Kidwell, K.K. Glyphosate inhibits rust diseases in glyphosate-resistant wheat and soybean. Proc. Natl. Acad. Sci. USA 2005, 102, 17290-17295. [CrossRef] [PubMed]

58. Feng, P.C.C.; Clark, C.; Andrade, G.C.; Balbi, M.C.; Caldwell, P. The control of Asian rust by glyphosate in glyphosate-resistant soybeans. Pest. Manag. Sci. 2008, 64, 353-359. [CrossRef] [PubMed]

59. Nelson, K.A.; Renner, K.A.; Hammerschmidt, R. Cultivar and herbicide selection affects soybean development and the incidence of Sclerotinia stem rot. Agron. J. 2002, 94, 1270-1281. [CrossRef]

60. Nelson, K.A.; Renner, K.A.; Hammerschmidt, R. Effects of Protoporphyrinogen oxidase inhibitors on soybean (Glycine max L.) response, Sclerotinia sclerotiorum disease development, and phytoalexin production by soybean. Weed Technol. 2002, 16, 353-359. [CrossRef]

61. Corrêa, M.J.P.; Alves, P.L.; Da, C.A. Effects of herbicides application on photochemical efficiency in conventional and genetically modified soybeans. Ciênc. Agrotec. 2010, 34, 1136-1145. [CrossRef]

62. Katan, J.; Eshel, Y. Interactions between herbicides and plant pathogens. In Residue Reviews; Gunther, F.A., Gunther, J.D., Eds.; Springer: New York, NY, USA, 1973.

63. Araújo, A.S.F.; Monteiro, R.T.R.; Abarkeli, R.B. Effect of glyphosate on the microbial activity of two Brazilian soils. Chemosphere 2003, 52, 799-804. [CrossRef]

64. Boyette, C.D.; Reddy, K.N.; Hoagland, R.E. Glyphosate and bioherbicide interaction for con-trolling kudzu (Pueraria lobata), redvine (Brunnichia ovata), and trumpetcreeper (Campsis radicans). Biocontrol. Sci. Tech. 2006, 16, 1067-1077. [CrossRef]

65. Amin, M.; Melkamu, F. Management of Ascochyta Blight (Ascochyta rabiei) in chickpea using a new fungicide. Res. Plant Biol. 2014, 2, 27-32.

66. Bretag, T.W.; MacLeod, W.J.; Kimber, R.B.E.; Moore, K.J.; Knights, E.J.C.; Davidson, J.A. Management of ascochyta blight in chickpeas in Australia. Australas. Plant Path. 2008, 37, 486-497. [CrossRef]

67. Davidson, J.A.; Kimber, R.B.E. Integrated disease management of ascochyta blight in pulse crops. Eur. J. Plant Pathol. 2007, 119, 99-110. [CrossRef]

68. Sudheesh, S.; Rodda, M.S.; Davidson, J.; Javid, M.; Stephens, A.; Slater, A.T.; Cogan, N.O.I.; Forster, J.W.; Kaur, S. SNP-based linkage mapping for validation of QTLs for resistance to Ascochyta blight in lentil. Front. Plant Sci. 2016, 7, 1604. [CrossRef] [PubMed]

69. Małecka, I.; Sawinska, Z.; Blecharczyk, A.; Dytman-Hagedorn, M. Zdrowotność pszenicy ozimej w różnych wariantach uprawy roli. Prog. Plant Prot. Post. Ochr. Roślin 2014, 54, 246-250. (In Polish)

70. Sułek, A.; Podolska, G.; Jaśkiewicz, B. Plonowanie i zdrowotność dwóch podgatunków pszenicy w zależności od udziału zbóż w strukturze zasiewów w warunkach integrowanej produkcji. Pol. J. Agron. 2016, 27, 118-125. (In Polish)

71. Strom, N.; Hu, W.; Haarith, D.; Chen, S.; Bushley, K. Interactions between soil properties, fungal communities, the soybean cyst nematode, and crop yield under continuous corn and soybean monoculture. Appl. Soil Ecol. 2020, 147, 103388. [CrossRef]

72. Kraska, P.; Andruszczak, S.; Kwiecińska-Poppe, E.; Pałys, E. The effect of tillage systems and catch crops on the yield, grain quality and health of spring wheat. Acta Sci. Pol. Agric. 2014, 13, 21-38. 
73. Supronienė, S.; Mankeviĉienė, A.; Kadžienė, G.; Kaĉergius, A.; Feiza, V.; Feizienė, D.; Semaškienė, R.; Dabkeviĉius, Z.; Tamošiūnas, K. The impact of tillage and fertilization on Fusarium infection and mycotoxin production in wheat grains. Zemdirbyste 2012, 99, 265-272.

74. Vrandečić, K.; Jug, D.; Ćosić, J.; Stošić, M.; Poštić, J. The impact of tillage and fertilization on soybean grain infection with fungi. Rom. Agric. Res. 2014, 31, 139-145.

75. Gawęda, D.; Nowak, A.; Haliniarz, M.; Woźniak, A. Yield and economic effectiveness of soybean grown under different cropping systems. Int. J. Plant Prod. 2020, 53, 1-11. Available online: https://link.springer. com/article/10.1007/s42106-020-00098-1\#article-info (accessed on 29 April 2020). [CrossRef]

(C) 2020 by the authors. Licensee MDPI, Basel, Switzerland. This article is an open access article distributed under the terms and conditions of the Creative Commons Attribution (CC BY) license (http://creativecommons.org/licenses/by/4.0/). 